\title{
Investigating a Blended Learning Environment: Contribution of Attitude, Interaction, and Quality of Teaching to Satisfaction of Graduate Students of TEFL
}

\author{
Mahboubeh Taghizadeh $^{1}$ (I) Fatemeh Hajhosseini $^{1}$
}

Published online: 26 August 2020

(C) The Author(s) 2020

\begin{abstract}
The level of learner satisfaction, according to Chen and Yao (J Educ Res 4(7):1667-1671, 2016), has a main role in measuring the effectiveness of blended learning, which is influenced by various factors. The purpose of this study was thus twofold: (a) to explore graduate students' attitudes, interaction patterns, and satisfaction with blended learning technology and (b) to investigate the extent to which attitude, interaction, and quality of teaching contributed to satisfaction. The participants of this study were 140 graduate students of TEFL at the e-learning campus of Iran University of Science and Technology. The instruments were four types of questionnaire on learner satisfaction, attitude, interaction types, and quality of teaching. The results of quantitative and qualitative analysis revealed learners' positive attitudes towards blended learning technology. The instructor was also successful in teaching theoretical and practical concepts of TEFL, guiding online discussion through giving constructive feedback, and motivating learners to do more online learning. Learner--instructor interaction was also found to be the most frequent type of interaction. The results of multiple regression analysis also revealed that contribution of quality of teaching to satisfaction was higher than that of interaction and attitude, implying the significance of training online teachers to enhance their knowledge, skills, and strategies required for online teaching.
\end{abstract}

Mahboubeh Taghizadeh

mah_taghizadeh@iust.ac.ir

Fatemeh Hajhosseini

faranak.mehrad@yahoo.com

1 Department of Foreign Languages, Iran University of Science and Technology, Hengam Street, Resalat Square, Tehran, Iran
Keywords Attitude - Blended learning - Interaction · Quality of teaching $\cdot$ Satisfaction

\section{Introduction}

Blended learning, according to Kvavik (2005), is an innovative method for learners, making learning and teaching process more comfortable and attractive and is in accordance with learners' needs for the 21st century. Blended learning is referred to as a combination of online and face-to-face instruction (Graham 2006), and it is argued that learners can learn easily through this method (Teclehaimanot and Lamb 2005; Wetzel et al. 2014), because this method is supported by the theory of experiential learning (Seaman et al. 2017). Sharma (2010) asserts that blended learning attempts to generate a harmonious balance between face-to-face interaction and online access to knowledge by considering teachers' and learners' attitudes and aptitudes.

Willging and Johnson (2009) note that the main factor influencing online courses is learner satisfaction, which is the amount of learner's attitude and feelings about all advantages of blended learning classrooms (Wu et al. 2010). According to Chang and Fisher (2003), learner satisfaction is the main factor that can influence the success and failure of using new methods of teaching and learning and is an essential factor for implementing the program of blended learning. Learner satisfaction is found to motivate, engage, and influence the learning, efficiency, and the achievement of learners (Wickersham and McGee 2008). Bollinger and Martindale (2004) state that learner satisfaction with blended learning technology depends on 
various factors, including instruction, interaction, instructor, technology, and course management issues.

Selim (2007) asserts that one of the main factors to measure learner satisfaction and success is optimistic attitudes to blended learning. According to Zhu et al. (2013), learner's attitude deals with learner's readiness for using blended learning, and learners with positive attitudes can have higher level of motivation for online learning. In addition, different types of interaction can play a significant role in online learning community; for instance, learner-learner interaction is found to be a principal factor for satisfaction (Sher 2009). Learner-instructor interaction is also one of the most important factors, which predicts satisfaction with online courses (Thurmond 2003; Bolliger and Martindale 2004; Battalio 2007). Anderson et al. (2001) state that teachers have a main role in creating and retaining teaching presence.

Nowadays, e-learning campuses in which students also have some face-to-face sessions and have been established at the well-known universities in Iran, including Iran University of Science and Technology (IUST); hence, the most important issues that come into vogue are the learner satisfaction and how it would be possible to boost learner satisfaction level in terms of learners' attitude, interaction, and quality of teaching. The relationship between online satisfaction and attitude (Unsal 2007; Acar 2013; Kintu and Zhu 2016), satisfaction and quality of teaching (Alebaikan and Troudi 2010), and satisfaction and interaction (Ekwunife-Orakwue and Teng 2014; Kassandrinouet et al. 2014) have been investigated; however, it seems the discipline still lacks in-depth studies on learner satisfaction with blended learning technology, specifically it appears there is no study investigating the contribution of attitude, interaction, and quality of teaching to satisfaction of graduate students of TEFL with blended learning classrooms. Therefore, the main objective of this study was to explore TEFL graduate students' attitudes, interaction patterns, and their satisfaction with blended learning. This study also aimed at determining the extent to which attitude, interaction, and quality of teaching contributed to learners' satisfaction with blended learning. Accordingly, the following research questions were addressed in this study:

RQ1: What are graduate students' attitudes towards blended learning?

RQ2: What interaction types are used by graduate students of TEFL in blended learning classrooms?

RQ3: What factors can affect the quality of teaching in blended learning?

RQ4: What are graduate students' perceptions of satisfaction with blended learning technology?
RQ5: To what extent do attitude, interaction, and quality of teaching contribute to graduate students' satisfaction with blended learning?

\section{Review of the Related Literature}

Blended learning, according to Graham (2013), is a combination of face-to-face and learning by the use of technology, which can enhance student-centered form of learning, help learners interact more freely, and increase time management (Poon 2013). Osguthorpe and Graham (2003) note that blended learning focuses on students' needs, improving flexibility, satisfaction, and critical thinking skills. Given the impact of blended learning on academic performance, it is found that students gained higher proficiency (Ladyshewsky 2004; Owstton et al. 2013), while learners who failed to engage in online tasks or perform the online activities and assignments tended to show lower academic performance (Pérez and Riveros 2014; Chen and DeBoer 2015). According to Park and Choi (2009), the disability of students in using blended learning technology has been due to some factors, including high workload, little timfe for study, and lack of family support.

One of the main factors to measure learner satisfaction and success is considered as optimistic attitudes to blended learning (Selim 2007; Kintu et al. 2017). Due to ease of use and the process of learning, learners are found to have positive attitudes to blended learning (Adas and Wafa 2011). Adas and Wafa also note that Internet accessibility and learners' IT skills can influence their attitude to blended learning. Language instructors also prefer to use blended learning in English classes due to its instructional improvement, its ease of data use, social interaction, personal activity, and easy correction (Osguthorpe and Graham 2003).

According to Ibrahim Abbas (2017), learners interact with the contents of the online courses and peers to avoid isolation. It is also argued that interaction helps learners link or integrate their traditional knowledge with their new information to make new concepts (Juwah 2006). The cooperative online learning, little friction, and the efficiency of online learning are considered as significant contributors to effective interaction (Juwah 2006; Lee 2012; Nandi et al. 2012). Jain (2011) notes that using technology based on appropriate pedagogy in online learning can also increase the effect of interactive process among learners and teachers.

Lack of learner-learner interaction, according to Lewis (2011), can have negative effect on online learning process. Ekwunife-Orakwue and Teng (2014) also argue that 
student-student interaction can influence student satisfaction, but it could not influence their grades. It is argued that the most essential type of interaction in online learning is learner-instructor interaction (Battalio 2007), as it can predict satisfaction with online course (Swan 2001; Thurmond 2003; Bolliger and Martindale 2004). Likewise, as stated by Thurmond (2003), the performance, participation, and satisfaction of graduate and undergraduate students in online courses are influenced by learner-instructor interaction.

According to Ibrahim Abbas, the instructors have significant role in online classes, as they can provide instructional contents and prepare learning environment for learners in blended courses. To simplify learning process, online instructors can use some methods, such as reviewing learners' posts, completing the course activities, and giving reflective feedback (Garrison et al. 2010). Other methods which can lead to effective instruction are continuously assessing learners' performance and providing learners with timely educational feedback (Arbaugh et al. 2008). It is argued that for teaching in blended learning environment, knowing different instructional approaches, methods, activities, and theories is more essential than face-to-face teaching environment (Dereshiwsky 2013; Sadera et al. 2014)

Ekwunife-Orakwue and Teng (2014) investigated satisfaction and learning outcomes in blended learning. The results revealed that learner-content interaction influenced learner satisfaction more than the other types of interaction. Fullwood (2015) investigated perceptions of online learners and their satisfaction with online communication. The results indicated that using online communication platforms could decrease lack of real interaction and increase student satisfaction with online and technological tools. Results also showed that using this method could influence interaction between instructor and learners and could decrease negative attitude towards the use of blended learning. Kintu and Zhu (2016) investigated self-organization, computer skills, satisfaction, and attitudes towards the use of blended learning in Ugandan University. They investigated other important factors (i.e., motivation, required information, and performance) for learning outcomes and blended learning design characteristics, such as quality of technology, interactions of learner and technological tools, and Moodle. The results showed that learners' attitudes towards blended learning were important influencing their motivation and satisfaction. Learner interaction was also found as an important factor among the design characteristics of blended learning.

\section{Method}

\section{Participants}

This study was conducted with 140 Iranian MA students who were passing TEFL at the e-learning campus of IUST, which was offering blended learning courses to graduate students. In other words, apart from online courses, learners were offered at least two sessions of face-to-face classes, which could be increased as further needs arose. The participants were female $(f=118, \%=84.3 \%)$ and male $(f=22, \%=15.7 \%)$ students, ranging in age from 23 to 51. Some of whom were student teachers with no teaching experience, while some had teaching experience ranged from 1 to 23 years and were teaching English Language in different schools and institutes in Iran. The participants were asked to convey their opinions about the teaching English language courses (i.e., Teaching Methodology, Teaching English Language Skills, and Teaching English for Academic Purposes) offered by a PhD holder in TEFL who was a young professor with 10 years of teaching experience at university level and express the level of their satisfaction with her methods of teaching in blended learning classrooms.

\section{Instruments}

Four questionnaires on learner satisfaction, attitude, interaction, and quality of teaching along with a semi-structured interview with eight questions were the instruments of this study. The satisfaction questionnaire was classified into five parts: interaction ( 9 items), instruction (12 items), instructor (5 items), technology (6 items), and course management ( 3 items) and was developed by Naaj et al. (2012). This questionnaire with 35 items was a five-point Likert scale, which ranged from $(5=$ strongly agree, 4 = agree, 3 = neutral, 2 = disagree, and $1=$ strongly disagree). The attitude questionnaire was developed by Dwaik et al. (2016) and included 15 items with five options ( 5 = strongly agree, $4=$ agree, $3=$ neutral, $2=$ disagree, and 1 = strongly disagree).

The questionnaire on interaction developed by Kuo et al. (2014) aimed to determine learners' interaction types in blended learning classrooms. This questionnaire with 18 items consisted of three parts of learner-learner interaction (items 1-8), learner-instructor interaction (items 9-14), and learner-content interaction (items 15-18), which appeared in five options $(5=$ strongly agree, $4=$ agree, $3=$ neutral, 2 = disagree, and $1=$ strongly disagree). To evaluate the instructors' performance, the quality of teaching questionnaire with seven items developed by Ginns and Ellis (2007) was also used in this study. It was a 
five-point Likert-type scale in which the respondents specified their level of agreement to each item in five points: (5) strongly agree, (4) agree, (3) neutral, (2) disagree, and (1) strongly disagree. A semi-structured interview with eight questions was also conducted with 30 students. The purpose of interview was to explore their viewpoints about the significance of attitude, quality of teaching, and patterns of interaction for their satisfaction with blended learning technology.

\section{Procedure}

This study was conducted in the first semester of the academic year 2019. The translated versions of the questionnaires on learner satisfaction, attitudes, interaction, and quality of teaching were administered to the participants of the research, but before that, the instruments were piloted with 20 online graduate students, and the necessary changes were made based on the students' responses. Cronbach's alpha was performed to estimate the consistency of the participants' responses to the items of the questionnaires. The reliability coefficients were estimated as follows: satisfaction $(r=0.898)$, attitude $(r=0.919)$, interaction (0.907), and quality of teaching $(r=0.909)$. A semi-structured interview was also conducted with 30 online students.

\section{Data Analysis}

Descriptive statistics for items and categories of the questionnaires were conducted to investigate graduate students' viewpoints about satisfaction, attitude, interactional patterns, and quality of teaching in a blended learning environment. Moreover, multiple regression analysis was used to determine the contribution of the three independent variables of attitude, interaction, and quality of teaching to students' satisfaction with blended learning. Finally, content analysis was done to determine learners' frequent responses to the interview questions, and then the frequency of each pattern in their responses was computed.

\section{Results}

\section{Learners' Attitudes to Blended Learning}

The highest amount of positive replies to items of the attitude questionnaire was related to the following items, respectively: 'Technology offers learners and teachers different options in learning and teaching' (100\%); 'Technology must be used in TEFL classes' (97.2\%); 'Technology facilitates the teaching/learning process' (97.2\%); 'Computers are effective tools in language instruction' (97.1\%); 'Blended learning can be used effectively in TEFL classes' (90\%); 'Using blended learning in English classes can offer comfortable teaching learning environment' (85.7\%); 'Blended learning promotes the learners' motivation' (84.3\%); 'Blended learning facilitates learning the theoretical aspects of TEFL' $(84.3 \%)$; and 'Blended learning promotes the learners' achievement' (84.2\%).

The first interview question, What is your opinion about the use of computer and technology in TEFL classes? Do you think it can help improve your knowledge?, was administered to highlight more insight into the use of technologies in online TEFL classes, and the learners' responses are hierarchically presented as follows: 'In digital era, using technological tools is very useful' $(f=29$, $\%=96.6$ ); 'Accessibility and variety of materials make the online environments more attractive than face-to-face classes' $(f=25, \%=83.3)$; 'Students can listen to files of online classes several times, reviewing materials to understand better' $(f=24, \%=80)$; 'Online learning can promote students' self-confidence' $(f=25, \%=83.3)$; 'In blended learning, learners are able to solve their instructional problems in face-to-face meetings' $(f=24, \%=80)$; 'Using blended learning technology is more useful for employed and married students, as it can save their time, energy, and money, allowing them to connect to online classes from different cities' $(f=23, \%=76.6)$; 'Concentration on learning is increased due to the omission of some factors, including stress and traffic' $(f=20$, $\%=66.6$ ); 'It can improve the motivation and interest of learners because of ease of use and the accessibility of course contents' ( $f=20, \%=66.6)$; 'Learners can communicate with other specialists in their field through using Internet, email, or other technological tools' $(f=19$, $\%=63.3$ ); 'Blended learning can help students promote their knowledge about TEFL' $(f=18, \%=60)$; 'Using blended learning can considerably develop listening and writing skills' $(f=15, \%=50)$; 'Blended learning can motivate students to study more' ( $f=8, \%=26.6)$; and 'It can decrease the amount of stress, especially for introverted students who lack self-confidence' $(f=5, \%=16.6)$. However, some of the learners had negative attitude, stating that 'using new technological tools is somewhat difficult for older students' $(f=2, \%=6.6)$; and 'learning in face-to-face classes is better than online ones due to the more interaction between students and teacher' $(f=1$, $\%=3.4)$.

\section{Learners' Interaction in Blended Learning Classrooms}

In order to determine the learners' interaction types in blended learning classrooms, the percentage of learners' 
agreement and disagreement about each item in the questionnaire is provided in Table 1. It is important to highlight the fact that in this part the combined results for 'agree' and 'strongly agree' categories are considered as the positive responses, while the combined results for the categories of 'disagree' and 'strongly disagree' are considered as the negative responses.

As shown in Table 1, The highest amount of positive responses to items of the interaction questionnaire was as follows: 'It is easy for me to access the online course materials' (92.9\%); 'I receive enough feedback from my instructor when I need it' (90\%); 'The instructor regularly posts some questions for students to discuss on the discussion board' '(84.3\%); 'The instructor replies my questions in a timely fashion' (84.3\%); 'I reply to messages from the instructor' (82.9\%); 'I answer questions of my classmates through different electronic means, such as email, discussion board, and instant messaging tools' (78.6\%); 'Online course materials stimulate my interest for this course' (78.6\%); and 'Online course materials help me to understand better the class content' $(77.2 \%)$. On the contrary, the highest amount of disagreement was obtained by the following statements, respectively: 'I comment on other students' thoughts and ideas' (34.3\%); 'I get lots of feedback from my classmates' (30\%); 'Overall, I have numerous interactions related to the course content with fellow students' (28.5\%); 'Group activities during class give me chances to interact with my classmates' (21.4\%); and 'I share my thoughts or ideas about the lectures and its application with other students during this class' (15.8\%).

As indicated in Table 2, the highest amount of mean $(M=4.06)$ was related to 'learner-instructor interactions' $(M=4.06)$ whereas the lowest amount of mean belonged to 'learner-learner interactions' $(M=3.41)$. Table 2 also shows that the responses to the items related to learnercontent category were the most homogeneous $(\mathrm{SD}=0.63$ ), whereas those belonging to learner-learner interaction were the most heterogeneous $(\mathrm{SD}=0.74)$. To determine the relationship among categories of interaction types in blended learning, Pearson product moment correlation was conducted. As shown in Table 2, the correlation between learner-learner and learner-instructor interactions was

Table 1 Percentages of interaction patterns in blended learning classroom

\begin{tabular}{|c|c|c|c|c|c|}
\hline Statements & $\begin{array}{l}\text { Strongly } \\
\text { disagree }\end{array}$ & Disagree & Neutral & Agree & $\begin{array}{l}\text { Strongly } \\
\text { agree }\end{array}$ \\
\hline \multicolumn{6}{|l|}{ Learner-learner interactions } \\
\hline 1. Overall, I have numerous interactions related to the course content with fellow students & 1.4 & 27.1 & 25.7 & 35.7 & 10.0 \\
\hline 2. I get lots of feedback from my classmates & 1.4 & 28.6 & 28.6 & 35.7 & 5.7 \\
\hline $\begin{array}{l}\text { 3. I communicate with my classmates about the course content through different electronic } \\
\text { means, such as email, discussion boards, and instant messaging tools }\end{array}$ & 1.4 & 12.9 & 14.3 & 50.0 & 21.4 \\
\hline $\begin{array}{l}\text { 4. I answer questions of my classmates through different electronic means, such as email, } \\
\text { discussion board, and instant messaging tools }\end{array}$ & 1.4 & 8.6 & 11.4 & 54.3 & 24.3 \\
\hline $\begin{array}{l}\text { 5. I share my thoughts or ideas about the lectures and its application with other students } \\
\text { during this class }\end{array}$ & 2.9 & 12.9 & 24.3 & 47.1 & 12.9 \\
\hline 6. I comment on other students' thoughts and ideas & 2.9 & 31.4 & 30.0 & 27.1 & 8.6 \\
\hline 7. Group activities during class give me chances to interact with my classmates & 1.4 & 20.0 & 28.6 & 42.9 & 7.1 \\
\hline 8. Class projects lead to interactions with my classmates. & 1.4 & 28.6 & 21.4 & 38.6 & 10.0 \\
\hline \multicolumn{6}{|l|}{ Learner-instructor interactions } \\
\hline 9. I have numerous interactions with the instructor during the class. & 4.3 & 11.4 & 21.4 & 41.4 & 21.4 \\
\hline $\begin{array}{l}\text { 10. I ask the instructor my questions through different electronic means, such as email, } \\
\text { discussion board, and instant messaging tools. }\end{array}$ & - & 8.6 & 20.0 & 37.1 & 34.3 \\
\hline $\begin{array}{l}\text { 11. The instructor regularly posts some questions for students to discuss on the discussion } \\
\text { board. }\end{array}$ & - & 7.1 & 8.6 & 45.7 & 38.6 \\
\hline 12. The instructor replies my questions in a timely fashion. & - & 2.9 & 12.9 & 44.3 & 40.0 \\
\hline 13. I reply to messages from the instructor & - & 1.4 & 15.7 & 48.6 & 34.3 \\
\hline 14. I receive enough feedback from my instructor when I need it & - & 4.3 & 5.7 & 52.9 & 37.1 \\
\hline \multicolumn{6}{|l|}{ Learner-content interactions } \\
\hline 15. Online course materials help me to understand better the class content. & - & 7.1 & 15.7 & 48.6 & 28.6 \\
\hline 16. Online course materials stimulate my interest for this course & 1.4 & 7.1 & 12.9 & 58.6 & 20.0 \\
\hline $\begin{array}{l}\text { 17. Online course materials help relate my personal experience to new concepts or new } \\
\text { knowledge }\end{array}$ & - & 5.7 & 21.4 & 55.7 & 17.1 \\
\hline 18. It is easy for me to access the online course materials. & - & 2.9 & 4.3 & 64.3 & 28.6 \\
\hline
\end{tabular}


Table 2 Correlation analysis and descriptive statistics of the types of interaction in blended learning $(N=140 ; * *=\mathrm{p}<.05)$

\begin{tabular}{|c|c|c|c|c|c|}
\hline Categories & 1 & 2 & 3 & $M$ & SD \\
\hline 1. Learner-learner & - & $.344 * *$ & $.501 * *$ & 3.41 & .74 \\
\hline 2. Learner-instructor & & - & $.580 * *$ & 4.06 & .67 \\
\hline 3. Learner-content & & & - & 3.97 & .63 \\
\hline
\end{tabular}

0.344 , indicating a moderate, positive correlation. In contrast, there was a high, positive correlation between the learner-learner and learner-content interactions $(r=0.501)$ and the learner-content and learner--instructor interactions $(r=0.580)$.

The learners' response to the question, How do you communicate with your classmates in blended learning classrooms, can be summarized as follows: 'Learners communicate with their classmates through social networks, such as Telegram and WhatsApp to solve their educational problems and share useful materials' $(f=26$, $\%=86.6$ ). Learners were also asked whether they had successful interaction with other learners. Their responses were 'depending on their personality type, as some of the learners are active in groups, while others are passive' $(f=26, \%=86.6)$; 'Some have cooperative attitude, improving the learning quality in online classes; for instance, they share their summaries and explanations with other members of the group' ( $f=15, \%=43.3)$; and 'due to lack of time, some do their assignments individually and have low interaction with their classmates' $(f=10$, $\%=33.3)$.

\section{Quality of Teaching in Blended Learning Classroom}

Descriptive statistics were used to explore graduate students' perceptions of the quality of teaching in blended learning classrooms. The results for the 'agree' and 'strongly agree' options for each item of the questionnaire were considered as the positive responses, while the combination of the two other options (i.e., disagree and strongly disagree) for each item was considered as the negative replies. Results are presented in Table 3.

Table 3 indicates that most positive replies were related to the following items, respectively: 'The teacher's interaction with me online encourages me to get the most out of my learning' (78.6\%); 'The teacher's responses online motivate me to learn more deeply' (77.2\%); 'The teacher helps to focus online discussions between students' (77.2\%); 'The teacher helps to guide online discussions between students' (77.1\%); and 'I receive too much feedback online from my teacher' (70\%). However, the highest amount of disagreement was obtained by 'The teacher's online responses motivate me to do more online learning than I would have done otherwise' (17.2\%).
Learners' responses to the interview question, Does the teacher help to guide online discussions among students to increase their motivation for learning?, were as follows: 'The instructor gives prompt feedback, enhancing learners' motivation for learning' $(f=27, \%=90)$; 'The instructor answers all questions and gives feedback to students' all comments' $(f=27, \%=96.6)$; 'Instructor gives hints to help students find correct answers' $(f=27, \%=90)$; 'Instructor's feedback can help learners get familiar with their learning strengths and weaknesses' $(f=25, \%=90)$; 'Instructor's greetings motivate us to participate actively in the class' $(f=25, \%=83.3)$; 'The instructor explains the theories by giving examples from real world' $(f=23$, $\%=76.6)$; 'Learners are allowed to share their teaching concerns with the instructor' $(f=23, \%=76.6)$; 'The instructor guides class discussion and creates a link between learners' prior and new information, helping learners to understand better' $(f=22, \%=73.3)$; 'The positive personality of the instructor is one of the main factors, which fosters motivation' $(f=21, \%=70)$; 'The instructor asks learners to send their teaching practice via WhatsApp and gives them feedback to improve their teaching skills' $(f=18, \%=60)$; 'The instructor is connected to the class from the e-learning campus of IUST, so her voice quality was very high' $(f=28, \%=93.3)$; 'Instructor is able to work with essential technologies and tools' $(f=26, \%=86.6)$; and 'At the beginning of the semester, the instructor informed us of the course syllabus, assignments, and term projects with their deadlines' $(f=25, \%=83.3)$.

\section{Learner Satisfaction with Blended Learning}

With regard to learner satisfaction, the most positive replies were obtained by the following items, respectively: 'I enjoy working on assignments by myself' (92.8\%); 'Course content displayed on the smart board is clear' (91.4\%); 'The use of blended learning technology in this course encourages me to learn independently' (88.6\%); 'The instructor makes me feel that I am a true member of the class' (87.1\%); 'The lecturer/supervisor always takes attendance' ( $87.1 \%)$; 'The instructor uses blended learning technology appropriately' (85.7\%); 'Discipline is highly observed when the lecturer is on the other side of the blended learning classroom' (84.3\%); 'Class assignments 
Table 3 Percentages of learners' perceptions of the quality of teaching in blended learning classroom

\begin{tabular}{|c|c|c|c|c|c|}
\hline Statements & $\begin{array}{l}\text { Strongly } \\
\text { disagree }\end{array}$ & Disagree & Neutral & Agree & $\begin{array}{l}\text { Strongly } \\
\text { agree }\end{array}$ \\
\hline \multicolumn{6}{|l|}{ Quality of teaching } \\
\hline 1. I receive too much feedback online from my teacher & - & 11.4 & 18.6 & 47.1 & 22.9 \\
\hline 2. The teacher's responses online motivate me to learn more deeply & - & 5.7 & 17.1 & 48.6 & 28.6 \\
\hline 3. The teacher helps to guide online discussions between students & 1.4 & 1.4 & 20.0 & 41.4 & 35.7 \\
\hline $\begin{array}{l}\text { 4. The teacher's interaction with me online encourages me to get the most out of my } \\
\text { learning }\end{array}$ & - & 2.9 & 18.6 & 48.6 & 30.0 \\
\hline $\begin{array}{l}\text { 5. The teacher's online responses motivate me to do more online learning than I would } \\
\text { have done otherwise }\end{array}$ & 2.9 & 14.3 & 24.3 & 28.6 & 30.0 \\
\hline 6. I receive enough helpful online feedback from my teacher. & - & 10.0 & 20.0 & 42.9 & 27.1 \\
\hline 7. The teacher helps to focus online discussions between students & - & 1.4 & 21.4 & 42.9 & 34.3 \\
\hline
\end{tabular}

Table 4 Comparing the categories of satisfaction with blended learning technology $(N=140)$

\begin{tabular}{lllll}
\hline Categories of satisfaction & Min & Max & Mean & SD \\
\hline Technology & 1.67 & 5.00 & 3.80 & .83 \\
Course Management & 2.00 & 5.00 & 4.05 & .75 \\
Instruction & 2.67 & 4.67 & 3.58 & .40 \\
Instructor & 2.40 & 5.00 & 4.09 & .68 \\
Interaction & 2.33 & 5.00 & 3.45 & .42 \\
\hline
\end{tabular}

are clearly communicated to me' (78.6\%); 'I am satisfied enough with this course to recommend it to others' (77.2\%); 'I am satisfied with my participation in the class' (75.7\%); 'Interaction is adequately maintained with the lecturer when he/she is on the other side of the blended learning classroom' (74.2\%); 'The video image is clear and comprehensive when the lecturer is on the other side of the blended learning classroom' (71.4\%); and 'My understanding is improved compared to similar courses I studied before' $(70 \%)$. On the contrary, the highest amount of disagreement was obtained by the following statements, respectively. 'I cannot interrupt the lecturer to ask a question when he/she is on the other side of the blended learning classroom' (48.6\%); 'Compared to face-to-face course settings, I am less satisfied with this learning experience' $(48.6 \%)$; and 'I attend online classes the same way I attend face-to-face classes' (25.7\%).

As shown in Table 4, the highest mean was obtained by 'satisfaction with instructor' $(M=4.09)$, while the lowest mean belonged to 'satisfaction with interaction' $(M=3.45)$. Table 4 also indicates that the responses to the items of 'satisfaction with instruction' were the most homogeneous ( $\mathrm{SD}=0.40$ ), while those to the items of the 'satisfaction with technology' were the most heterogeneous $(\mathrm{SD}=0.83)$.

The last interview question, Are you satisfied with blended learning classrooms?, was asked from the learners and their responses are as follows, respectively: 'Most learners are employed and married with children, so learning through this method is very suitable for them' $(f=27, \%=90)$; 'Learning in blended classes is more than face-to-face ones' $(f=25, \%=83.3)$; 'Factors such as stress, physical presence, and wasting time are removed in this method' ( $f=24, \%=80)$; and 'Learners learn many theoretical and practical aspects of TEFL through blended learning technology' $(f=23, \%=76.6)$. However, some learners are dissatisfied, stating that 'blended learning technology is unknown in Iran, and many people have negative attitudes to its quality' $(f=4, \%=13.3)$, and 'there is no training and awareness about the advantages of using this technology' $(f=2, \%=6.7)$.

\section{Contribution of Attitude, Interaction, and Quality of Teaching to Satisfaction}

Multiple regression was run to determine the extent to which interaction, attitude, and quality of teaching predicted satisfaction with blended learning technology. Preliminary analyses were determined to ensure that there was no violation of the assumptions of normality, linearity, homoscedasticity, and multicollinearity. The results are provided in Table 5 .

As indicated in Table 5, quality of teaching, learners' attitude, and interaction could explain 79 percent of the 
Table 5 Summary of multiple regression analysis

\begin{tabular}{lllll}
\hline Model & $\mathrm{R}$ & $\mathrm{R}^{2}$ & Adjusted $\mathrm{R}^{2}$ & SE of the estimate \\
\hline 1 & .889 & .790 & .785 & .21758 \\
\hline
\end{tabular}

${ }^{\mathrm{a}}$ Dependent variable: satisfaction

${ }^{b}$ Predictors: quality of teaching, attitude, interaction

Table 6 ANOVA Results

\begin{tabular}{llrrrr}
\hline Model & & Sum of & $d f$ & Mean & F \\
squares & & & $p$ \\
\hline 1 & Regression & 24.202 & 3 & 8.067 & 170.412 \\
& Residual & 6.438 & 136 & .047 & .000 \\
& Total & 30.640 & 139 & & \\
& & & & \\
\hline
\end{tabular}

Dependent variable: satisfaction

Predictors: quality of teaching, attitude, interaction

variance in students' satisfaction with blended learning. To determine the statistical significance of these results, an ANOVA was administered. The result is presented in Table 6.

As shown in Table 6, the contribution of predictors (i.e., quality of teaching, attitude, and interaction) was statisti-

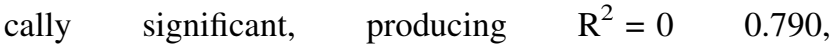
$F(3.136)=170.412, p=0.000$. To determine the relative contribution of each of the predictors to learner satisfaction, the coefficient for each variable was calculated, and the result indicated that the most contribution to satisfaction was obtained by quality of teaching $(47 \%)$, while the least contribution was related to learners' attitude to blended learning (14\%). The contribution of all indicators was also statistically significant: the quality of teaching (beta $=0.57, \quad p=0.000$ ), interaction $\quad($ beta $=0.34$, $p=0.000$ ), and attitude (beta $=0.16, p=0.000$ ).

\section{Discussion}

Given learners' attitudes to blended learning, the findings of this study showed that most students had positive attitude to blended learning technology, which could be related to factors such as providing different learning options through accessible and various materials, promoting motivation and self-confidence, enhancing their achievement and satisfaction, and saving their time and energy. These findings are in line with those of Kintu and Zhu (2016) and Kintu et al. (2017) who found that learners' positive attitudes to blended learning could create a high level of satisfaction with online courses. However, the findings are in contrast with those of Ja'ashan (2015), showing that attitudes of students' negative attitudes to blended learning were due to slow speed of Internet, lack of instructors' feedback to students' emails, and lack of face-to-face interaction.

The findings of this study also revealed that interaction between learners and instructor was the most frequent pattern of interaction in blended learning classrooms, which might be due to the fact that the instructor answered all students' online questions and concerns, gave prompt and effective feedback to all their comments, and interacted with them about course content through emails, social networks, and face-to-face sessions. Students also showed good interaction with online contents due to its accessibility, novelty, and relevance to their practice, which could also promote their interest for more academic endeavor. However, learner-learner interaction was the least frequent pattern of interaction since most students were busy and did not have enough time to participate actively in class or social network discussions. The findings of this study are supported by those of Hirumi (2002), indicating the role of instructor in designing learner-instructor interaction, suitable activities, assignments, and online materials to avoid learner dissatisfaction. The results of the study by Chejlyk (2006), Keeler (2006), and Moore and Kearsley (1996) also indicated that the highest level of student satisfaction belonged to learner-content interaction, which is in contrast with the finding of this study.

Given the results on the quality of teaching, the students noted that the instructor motivated them to participate in class discussion and activated their background knowledge about theoretical concepts of TEFL. Instructor could also manage the class discussion through giving constructive hints and feedback and could motivate them to ask and answer their questions to make the learning process easier. The findings of this study indicated that most learners were 
satisfied with blended learning classrooms of TEFL as different activities and assignments could help them improve interaction with instructors, content, and their classmates in this environment. The findings of this study are in line with those of Aliweh (2011), Adas and Wafa (2011), Bendania (2011), and Akkoyunlu and Soylu (2006), indicating learners' satisfaction with blended leaning technology. The finding also revealed that quality of teaching showed the greatest contribution to online satisfaction, which might be related to instructor's use of appropriate online materials, her punctuality and attendance, her successful interaction with students, and the quality of technological tools and good competence in using them, which promoted their achievement and interest for the course.

\section{Conclusions}

This study explored viewpoints of graduate students of TEFL about their attitudes, interaction patterns, quality of teaching, and the factors contributing to their satisfaction. The findings revealed that most learners had positive attitudes to blended learning technology and argued that learning in blended classes happens better than face-to-face ones as blended learning facilitates the teaching and learning process, enhances theoretical and practical knowledge, and promotes their self-confidence and motivation. In this study, the most frequent patterns of interaction was found between learners and instructor, which helped learners get familiar with their strengths and weaknesses and motivated them for further study.

Quality of teaching was found to be the most contributor to online satisfaction, indicating the importance of teacher educators' roles in improving instructor's knowledge and ability to teach online courses. In other words, training teachers about strategies and how to teach in blended learning environment is a pre-requisite for establishing blended learning in universities. In addition, course designers and materials developers need to design appropriate educational websites and online courses to promote online students' satisfaction, motivation, and interest in online courses. Policy-makers can also provide suitable training facilities for instructors to improve their knowledge about blended learning as instructors' role is very important for acceptance and implementation of this type of learning. Interaction with instructors, classmates, and contents are influential for satisfaction with blended learning; hence, instructors should try to consider these aspects in their teaching and try to acknowledge students' contribution and give constructive feedback to their comments. Teachers are also suggested to avoid teacher-centered classes, leading learners to be at the center of learning process; for example, they can give students group activities about course content to enhance their interaction with their classmates. Online instructors should be aware of learners' needs and abilities to choose the suitable contents and should increase the sense of group community among learners.

Future researchers can investigate the contribution of other variables, such as self-regulation, self-efficacy, autonomy, motivation, and barriers to satisfaction with blended learning. Further research can explore the relationship between satisfaction and learners' age, gender, online experience, and background knowledge about online education. Future researchers can conduct interview with online instructors to explore their viewpoints about factors contributing to online students' satisfaction. Another study can examine the impact of different interaction types on learner satisfaction with blended learning. Further study can be carried out investigating the factors which promote the quality of teaching and the skills and strategies required to improve instructors' knowledge and competence in blended learning classrooms.

Author Contribution MT involved in conceptualization, methodology, formal analysis, investigation, and supervision; FH performed writing - original draft preparation; FH and MT contributed to writing - review and editing; Funding acquisition: No funding; Resources: No resources were required.

\section{Compliance with Ethical Standards}

Conflicts of interest The authors declare that they have no conflicts of interest.

Ethical Approval All procedures performed in studies involving human participants were in accordance with the ethical standards of the institutional and/or national research committee (including Iran University of Science and Technology).

Informed Consent Informed consent was obtained from all individual participants included in the study. Additional informed consent was obtained from all individual participants for whom identifying information is included in this article.

Open Access This article is licensed under a Creative Commons Attribution 4.0 International License, which permits use, sharing, adaptation, distribution and reproduction in any medium or format, as long as you give appropriate credit to the original author(s) and the source, provide a link to the Creative Commons licence, and indicate if changes were made. The images or other third party material in this article are included in the article's Creative Commons licence, unless indicated otherwise in a credit line to the material. If material is not included in the article's Creative Commons licence and your intended use is not permitted by statutory regulation or exceeds the permitted use, you will need to obtain permission directly from the copyright holder. To view a copy of this licence, visit http://creativecommons.org/licenses/by/4.0/. 


\section{References}

Acar, A. (2013). Attitudes toward blended learning and social media use for academic purposes: An exploratory study. Journal of e-Learning and Knowledge Society, 9(3), 107-126.

Adas, D., Wafa, A. S. (2011). Students' perceptions towards blended learning environment using the OCC. An - Najah University Journal for Research (Humanities), 25(6), 1682-1710.

Akkoyunlu, B., \& Yilmaz-Soylu, M. (2006). A study on students' views on blended learning environment. Turkish Online Journal of Distance Education-TOJDE, 7(3), 43-56.

Alebaikan, R., \& Troudi, S. (2010). Blended learning in Saudi universities: Challenges and perspectives. ALT-J, Research in Learning Technology, 18(1), 49-59.

Aliweh, A. M. (2011). Exploring Egyptian EFL students' learning styles and satisfaction with web-based materials. CALICO Journal, 29(1), 81-99.

Anderson, T., Rourke, L., Garrison, D. R., \& Archer, W. (2001). Assessing teaching presence in a computer conferencing context. $J A L N, 5(2), 2-17$.

Arbaugh, J. B., Cleveland-Innes, M., Diaz, S. R., Garrison, D. R., Ice, P., Richardson, J. C., et al. (2008). Developing a community of inquiry instrument: Testing a measure of the community of inquiry framework using a multi-institutional sample. The Internet and Higher Education, 11(3-4), 133-136.

Battalio, J. (2007). Interaction online: A reevaluation. Quarterly Review of Distance Education, 8(4), 339-352.

Bendania, A. (2011). Teaching and learning online: King Fahd University of petroleum and minerals (KFUPM) Saudi Arabia case study. International Journal of Arts \& Sciences, 4(8), 223-241.

Bolliger, D. U., \& Martindale, T. (2004). Key factors for determining student satisfaction in online courses. International Journal of E-Learning, 3(1), 61-67.

Chang, V., \& Fisher, D. L. (2003). The validation and application of a new learning environment instrument for online learning in higher education. In M. S. Khine \& D. L. Fisher (Eds.), Technology-rich learning environments: A future perspective (pp. 1-20). Singapore: World Scientific Publishing.

Chejlyk, S. (2006). The effects of online course format and three components of student perceived interactions on overall course satisfaction (Doctoral dissertation). Dissertation Abstracts International, 67(04), UMI NO. 3213421.

Chen, X., DeBoer, J. (2015). Checkable answers: Understanding student behaviors with instant feedback in a blended learning class. Proceedings of 2015 IEEE Frontiers in Education Conference (FIE). El Paso, Texas, 1-5.

Chen, W. S., \& Yao, A. Y. (2016). An empirical evaluation of critical factors influencing learner satisfaction in blended learning: A pilot study. Universal Journal of Educational Research, 4(7), 1667-1671.

Dereshiwsky, M. (2013). Continual engagement: Fostering online discussion. River Falls, WI: Learning Resources Network.

Dwaik, R., Jweiless, A., \& Shrouf, S. (2016). Using blended learning to enhance student learning in American literature courses. The Turkish Online Journal of Educational Technology (TOJET), 15(2), 126-137.

Ekwunife-Orakwue, K. C., \& Teng, T. L. (2014). The impact of transactional distance dialogic interactions on student learning outcomes in online and blended environments. Computers \& Education, 78, 414-427.

Fullwood, C. (2015). The role of personality in online self-presentation. In A. Attrill (Ed.), Cyberpsychology (pp. 9-28). Oxford: Oxford University Press.
Garrison, D. R., Cleveland-Innes, M., \& Fung, T. S. (2010). Exploring causal relationships among teaching, cognitive and social presence: Student perceptions of the community of inquiry framework. The Internet and Higher Education, 13(1-2), 31-36.

Ginns, P., \& Ellis, R. (2007). Quality in blended learning: Exploring the relationships between on-line and face-to-face teaching and learning. The Internet and High Education, 10(1), 53-64.

Graham, C. R. (2006). Blended learning systems: Definition, current trends, and future directions. In C. J. Bonk \& C. R., Graham (Eds.), Handbook of blended learning: Global perspectives, local designs (pp. 3-21). San Francisco: Pfeiffer Publishing.

Graham, C. R. (2013). Emerging practice and research in blended learning. In M. G. Moore (Ed.), Handbook of distance education (pp. 333-350). New York, NY: Routledge.

Hirumi, A. (2002). A framework for analyzing, designing and sequencing planned e-learning interactions. Quarterly Review of Distance Education, 3(2), 141-160.

Ibrahim Abbas, Z. (2017). Blended learning and student satisfaction: An investigation into an EAP writing course. Advances in Language and Literary Studies, 9(1), 102-105.

Ja'ashan, N. H. (2015). Perceptions and attitudes towards blended learning for english courses: A case study of students at university of Bisha. English Language Teaching, 8(9), 40-50.

Jain, P. J. (2011). Interactions among online learners: A quantitative interdisciplinary study. Education, 131(3), 538-544.

Jung, L., Choi, S., Lim, C., \& Leem, J. (2002). Effects of different types of interaction on learning achievement, satisfaction and participation in web-based instruction. Innovations in Education and Teaching International, 39(2), 153-162.

Juwah, C. (Ed.). (2006). Interactions in online learning: Implications for theory and practice. New York: Routledge.

Kassandrinouet, A., Angelaki, C., \& Mavroidis, I. (2014). Transactional distance among open university students: How does it affect the learning process? European Journal of Open, Distance, and e-Learning, 17(1), 26-42.

Keeler, L. C. (2006). Student satisfaction and types of interaction in distance education courses (Unpublished doctoral dissertation). United States: Colorado State University.

Kintu, M. J., \& Zhu, C. (2016). Student characteristics and learning outcomes in a blended learning environment intervention in a Ugandan University. Electronic Journal of e-Learning, 14(3), 181-195.

Kintu, M. J., Zhu, C., \& Kagambe, E. (2017). Blended learning effectiveness: The relationship between student characteristics, design features and outcomes. International Journal of Educational Technology in Higher Education, 14(7), 1-20.

Kuo, Y.-C., Walker, A. E., Belland, B. R., Schroder, K. E. E., \& Kuo, Y. T. (2014). A case study of integrating interwise: Interaction, internet self-efficacy, and satisfaction in synchronous online learning environments. International Review of Research in Open and Distance Learning Journal, 15(1), 161-181.

Kvavik, R. B. (2005). Convenience, communications, and control: How students use technology. In D. Oblinger, J. L. Oblinger, \& J. K. Lippincott (Eds.), Educating the net generation (pp. 7.1-7.20). Brockport Bookshelf: New York.

Ladyshewsky, R. K. (2004). E-learning compared with the face to face: Differences in the academic achievement of postgraduate business students. Australasian Journal of Educational Technology, 20(3), 316-336.

Lee, J. (2012). Patterns of interaction and participation in a large online course: Strategies for fostering sustainable discussion. Educational Technology \& Society, 15(1), 260-272.

Lewis, J. L. M. (2011). The computer ate my classroom: Assessing student interactions, perceived learning, and satisfaction in online community college career technical education courses (Doctoral Dissertations). https://aquila.usm.edu/dissertations/510 
Moore, M. G., \& Kearsley, G. (1996). Distance education: A systems view. Belmont, CA: Wadsworth Publishing Company.

Naaj, M. A., Nachouki, M., \& Ankit, A. (2012). Evaluating student satisfaction with blended learning in a gender-segregated environment. Journal of Information Technology Education: Research, 11, 185-200.

Nandi, D., Hamilton, M., \& Harland, J. (2012). Evaluating the quality of interaction in asynchronous discussion forums in fully online courses. Distance Education, 33(1), 5-30.

Osguthorpe, B. R., \& Graham, C. R. (2003). Blended learning environments: Definitions and directions. The Quarterly Review of Distance Education, 4(3), 227-233.

Owston, R., York, D., \& Murtha, S. (2013). Student perceptions and achievement in a university blended learning strategic initiative. The Internet and Higher Education, 18(1), 38-46.

Park, J.-H., \& Choi, H. J. (2009). Factors influencing adult learners' decision to drop out or persist in online learning. Educational Technology \& Society, 12(4), 207-217.

Pérez, D. P., Riveros, R. M. (2014). Unleashing the power of blended learning and flipped classroom for English as foreign language learning: Tree spheres of challenges and strategies in a Higher education institution in Colombia. Proceedings of 7th International Conference of Education, Research and Innovation. Seville, Spain, 2829-2836.

Poon, J. (2013). Blended learning: An institutional approach for enhancing students' learning experiences. Journal of Online Learning and Teaching, 9(2), 271-288.

Sadera, W. A., O'Neil, C. A., \& Gould, K. A. (2014). Pedagogy associated with learning in online environments. In C. A. O'Neil, C. A. Fisher, \& M. J. Rietschel (Eds.), Developing online learning environments in nursing education (pp. 15-28). New York, NY: Springer Publishing Company LLC.

Seaman, J., Brown, M., \& Quay, J. (2017). The evolution of experiential learning theory: Tracing lines of research in the JEE. Journal of Experiential Education, 40(1), 1-20.

Selim, H. M. (2007). Critical success factors for e-learning acceptance: Confirmatory factor models. Computers \& Education, 49(2), 396-413.

Sharma, P. (2010). Key concepts in ELT. ELT Journal, 64(4), $456-458$.

Sher, A. (2009). Assessing the relationship of student-instructor and student-student interaction with student learning and satisfaction in web-based online learning environment. Journal of Interactive Online Learning, 8(2), 102-120.

Swan, K. (2001). Virtual interaction: Design factors affecting student satisfaction and perceived learning in asynchronous online courses. Distance Education, 22, 306-331.
Teclehaimanot, B., \& Lamb, A. (2005). Workshops that work: Building an effective, technology-rich faculty development program. Journal of Computing in Teacher Education, 21(3), $109-115$.

Thurmond, V. A. (2003). Examination of interaction variables as predictors of students' satisfaction and willingness to enroll in future web-based courses while controlling for student characteristics (Doctoral dissertation). https://www.bookpump.com/dps/pdf-b/1121814b.pdf

Ünsal, H. (2007). Evaluating the effectiveness of blended learning at multiple levels (Unpublished doctoral dissertation). Ankara: Gazi University.

Wetzel, K., Buss, R., Foulger, T. S., \& Lindsey, L. A. (2014). Infusing educational technology in teaching methods courses: Successes and dilemmas. Journal of Digital Learning in Teacher Education, 30(3), 89-103.

Wickersham, L. E., \& McGee, P. (2008). Perceptions of satisfaction and deeper learning in an online course. Quarterly Review of Distance Education, 9(1), 73-83.

Willging, P. A., \& Johnson, S. D. (2009). Factors that influence students' decision to drop-out of online courses. Journal of Asynchronous Learning Networks, 13(3), 115-127.

Wu, J. H., Tennyson, R. D., \& Hsia, T. L. (2010). A study of student satisfaction in a blended e-learning system environment. Computers and Education, 55(1), 155-164.

Zhu, Y., Au, W., Yates, G. (2013). University students' attitudes towards online learning in a blended course. Proceedings of the Australian Association for Research in Education (AARE). Adelaide, 2, 1-16.

Publisher's Note Springer Nature remains neutral with regard to jurisdictional claims in published maps and institutional affiliations.

Mahboubeh Taghizadeh is an Assistant professor in TEFL at the Iran University of Science and Technology. She holds a PhD in TEFL from University of Tehran, an MA in TEFL from Iran University of Science and Technology, and a BA in English Language and Literature from Az-Zahra University. She has published some national and international journals. She has also presented some papers at international conferences. Some of her current interests include CALL, Teacher Education, and EAP.

Fatemeh Hajhosseini graduated in TEFL from Iran University of Science and Technology. She has been teaching English for over 10 years. She has also presented some papers at national/international conferences. Some of her current interests include Teacher Education and CALL. 